Investigations

\title{
Meaning of the Oral Hygiene in Children, Due to Atherosclerosis Generation
}

\author{
${ }^{1}$ Anna Wójtowicz-Bujak and ${ }^{2}$ Andrzej Wolski \\ ${ }^{I} 22$ Bohaterów Wrzesnia Street, apt. 157 02-389 Warszawa, Poland \\ ${ }^{2} 8$ A Karminowa Street 21-002 Marysin, Poland
}

Article history

Received: 20-03-2015

Revised: 29-06-2015

Accepted: 23-07-2015

Correspondence Author: Anna Wójtowicz-Bujak 22 Bohaterów Wrzesnia Street, apt. 157 02-389 Warszawa, Poland

E-mail: annawojtowiczbujak@gmail.com

\begin{abstract}
Research focused on association between periodontal diseases and atherosclerosis has been substantial in recent years. It is now well known that chronic inflammation plays an important role in initiation and evolution of atherosclerosis. The bacterial plaque is a key pathology leading to periodontal inflammation. As reported by other authors, bacteria causing periodontal disease were found within the carotid arteries in adults, thus association between periodontal disease in childhood and peripheral vascular disease seem justifiable. The purpose of this study is to investigate the potential link between certain bacteria found in children with periodontal disease and the process of atherosclerosis in adults. Research was carried out in 97 children of which 58 aged between 6-14 comprised an experimental group, whereas 39 children aged of 6-13 comprised the control group. Based on physical examination, the oral hygiene in children of the experimental group was average or bad, while in children of the control group the oral hygiene was good. Blood samples and subgingival plaques were obtained to proceed with microbiological testing by PCR technique. The results of tests showed Aggregatibacter actinomycetemcomitans in 55\% and Prevotella intermedia in $79 \%$ of children in the experimental group. Only 2 cases of Prevotella intermedia were detected in the control group, however, no cases of Porphyromnas gingivalis were found in either groups. Full blood count, serum homocysteine, CRP, fibrinogen and HDL cholesterol values were normal in both groups. Total cholesterol value was increased in $24,14 \%$ in the experimental group vs. $5,15 \%$ in the control group, thus increase of total serum cholesterol concentration in children with bad oral hygiene may by a risk factor of atherosclerosis.
\end{abstract}

Keywords: Atherosclerosis, Childhood, Oral Hygiene, PCR, Periodontal Disease

\section{Introduction}

According to 2003 World Health Report, the annual global Cardiovascular Disease (CVD) mortality is 16.7 million (29.2\%). CVD typically involves a narrowing or even complete occlusion of the vascular lumen by atherosclerotic deposits, which may lead to death. The pathogenesis of atherosclerosis is multifactorial. There are well-established atherosclerotic risk factors, such as age, male sex, positive family history, diabetes, hypertension, obesity, smoking, low physical activity, elevated Low-Density Lipoprotein (LDL) and total cholesterol levels and decreased High-Density Lipoprotein (HDL) cholesterol (Urban et al., 2007;
Southerland et al., 2006). Recent years have seen an increased interest in the so-called new risk factors for atherosclerosis. This is mainly due to the fact that approximately $25 \%$ of patients with premature coronary heart disease show none of the well-established risk factors (Ridker et al., 1999). The new risk factors for atherosclerosis include lipoprotein (a), homocysteine, fibrinogen, C-Reactive Protein (CRP), oxidized LDL, small dense LDL particles, Asymmetric Dimethylarginine (ADMA), with a recent addition of an independent risk factor for $\mathrm{CVD}$, i.e. periodontal disease, which causes chronic inflammation (Rech et al., 2007; Dave and Van Dyke, 2008). Inflammation, in turn, inherently affects all stages in the development of 
atherosclerosis, from adhesion molecule expression on endothelial through fatty-streak and stable atherosclerotic plaque formation, all the way to atherosclerotic plaque destabilization and rupture (Szyguła-Jurkiewicz et al., 2004). In 2009, a panel of Polish experts issued a document on the role of periodontal disease in the pathogenesis of cardiovascular disease as well as recommendations as to its prevention (Górska, 2009). In 2010, the European Society of Cardiology published a consensus on the same topic (Bouchard et al., 2010). The periodontium is a morphological and functional entity comprising the gingiva, periodontal ligament, cementum and alveolar bone proper. The role of periodontium is to firmly hold teeth within dental alveoli of the maxilla and mandible. One factor that plays an unquestionable role in etiopathogenesis of periodontitis is dental plaque. It is an essential stage in initiating the inflammation typical for most conditions involving periodontal tissues. Dental plaque, together with various general factors, affects the body's immune processes and determines the extent and rate of inflammation. Dental plaque is a soft bacterial film adhering firmly to the surface of teeth and other hard surfaces within the oral cavity, including restorations (Haake et al., 1996). Bacteria comprising the plaque exhibit a wide variety, with approximately 300 bacterial species found in the oral cavity. However, the species considered pathogenic with respect to the periodontium are gramnegative anaerobes, including Aggregatibacter actinomycetemcomitans (Aa; previously Actinobacillus actinomycetemcomitans) (Norskov-Lauritsen and Kilian, 2006), Porphyromonas gingivalis (Pg), Bacteroides forsythus (Bf), Treponema denticola (Td), Eikenella corrodens (Ec), Campylobacter rectus (Cr), Prevotella intermedia (Pi) and Fusobacterium nucleatum (Fn). Dental plaque can be divided into supragingival plague colonized mainly by aerobic bacteria and subgingival plaque colonized by anaerobes. Polymerase Chain Reaction (PCR)-based assessments of atherosclerotic lesions in the carotid arteries showed the presence of Pg, Pi and Aa DNA (Górska, 2002). Some studies indicate that the presence of antibodies against bacteria causing periodontal disease may increase the risk of stroke, myocardial infarction and acute coronary syndrome (Pussinen et al., 2004; 2007; Renvert et al., 2006). Löe et al. (1965) demonstrated that the presence or lack of toothbrushing is the key factor determining the development of gingivitis. Those results proved that plaque is the reason of gingivitis. These findings pose a serious concern, especially in children, as epidemiological studies show that dental caries resulting from nonexistent or inadequate oral hygiene is a common problem in children and adolescents, affecting $87 \%$ of children aged 3-6 years, nearly $100 \%$ of $6-8$-year-olds, $79 \%$ of $8-12$-year-olds and over $90 \%$ of 12-19-year-olds (Olczak-Kowalczyk and Bedra, 2003).

\section{Materials and Methods}

A total of 97 children aged from 6 to 14 years were included in the study and allocated into two groups. The general health status in all study subjects was good. The study group comprised 58 subjects with fair to poor oral hygiene, including 29 girls and 29 boys. The mean age was 10.42 years. The control group consisted of 39 subjects with good to optimal oral hygiene, including 22 girls and 17 boys. The mean age was 9.31 years. All subjects underwent blood tests and had a sample of dental plaque collected for a microbiological PCR assessment. A questionnairebased history was taken in all subjects and included the general health status as well as environmental and genetic factors. Oral hygiene status was determined with the Approximal Plaque Index (API) (Lange et al. 1978). This index demonstrates the presence or lack of dental plaque in the interproximal surfaces from the oral aspect (quadrants 1 and 3) and the facial aspect (quadrants 2 and 4). The assessment was conducted with a periodontal probe and mirror, without the use of staining. The proportion of plaque-covered surfaces was expressed as a percentage and calculated according to the following formula:

$$
\text { API }=\left(\frac{\text { number of plaque }- \text { covered sites }}{\text { number of all sites examined }}\right) \times 100
$$

The results were evaluated according to the following scale: API $<25 \%$ optimum oral hygiene; API $25-39 \%$ good oral hygiene; API $40-70 \%$ fair oral hygiene requiring improvement; API 70-100\% poor oral hygiene. Only otherwise healthy children with API $70-100 \%$ or API $40-70 \%$ were included in the study group.

Dental plaque samples for a PCR assessment were collected from gingival pockets of all 58 study group subjects and 39 control group subjects. Firstly, the selected sampling site was dried with blotting paper. Then, a swab of supragingival dental plaque was collected, followed by subgingival plaque collection with a sterile periodontal probe. The samples were added into Eppendorf test tubes containing $0.1 \mathrm{~mL}$ of physiological saline each and frozen at $-25^{\circ} \mathrm{C}$ until molecular PCR testing. Genomic DNA was isolated from subgingival samples with a Genomie DNA from Tissue kit (Machery-Nagle) according to the manufacturer's instructions.

Multiplex 16S rRNA amplification protocol (Clonit) was used for detection of DNA of the following periodontal pathogens: Aa, Pg and Pi. The PCR mixture for positive and negative controls as well as for the evaluated samples was prepared according to the manufacturer's instructions (Fig. 1-3). 
Anna Wójtowicz-Bujak and Andrzej Wolski / American Journal of Infectious Diseases 2015, 11 (4): 102.112 DOI: 10.3844/ajidsp.2015.102.112

Table 1. Amplification of the isolated DNA, positive control and negative control (included in the kit) was conducted with a Biometria Thermocycler under the following conditions

\begin{tabular}{llll}
\hline No. of cycles & Denaturation & Annealing & Extension \\
\hline 1 & $95^{\circ} \mathrm{C}$ for $3 \mathrm{~min}$ & & $72^{\circ} \mathrm{C}$ for $1 \mathrm{~min}$ \\
\hline 30 & $95^{\circ} \mathrm{C}$ for $1 \mathrm{~min}$ & $70^{\circ} \mathrm{C}$ for $1 \mathrm{~min}$ & \\
\hline
\end{tabular}

Two-dimensional distribution: Group $\mathrm{x}$ gingival inflammation

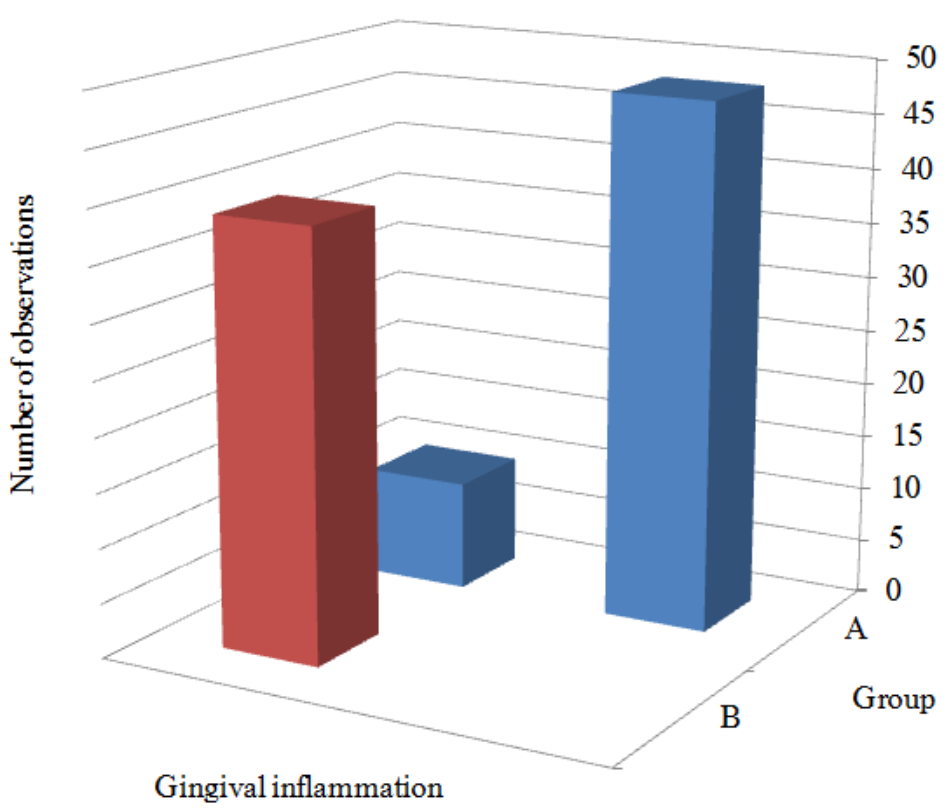

Fig. 1. A graphic representation of the control and study groups in terms of gingivitis (red - group B, blue - group A)

Two-dimensional distribution: Group x visible dental plaque

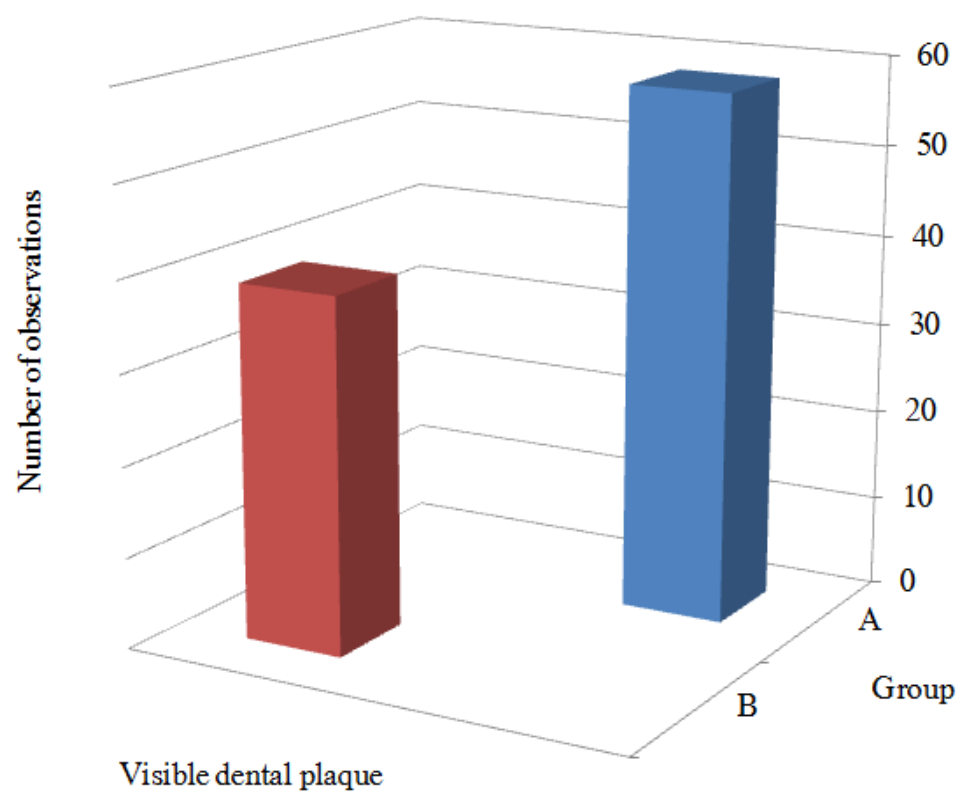

Fig. 2. A graphic representation of the control and study groups in terms of visible dental plaque (red - group B, blue -group A) 
Two-dimensional distribution: Group $\mathrm{x}$ number of teeth for the extraction

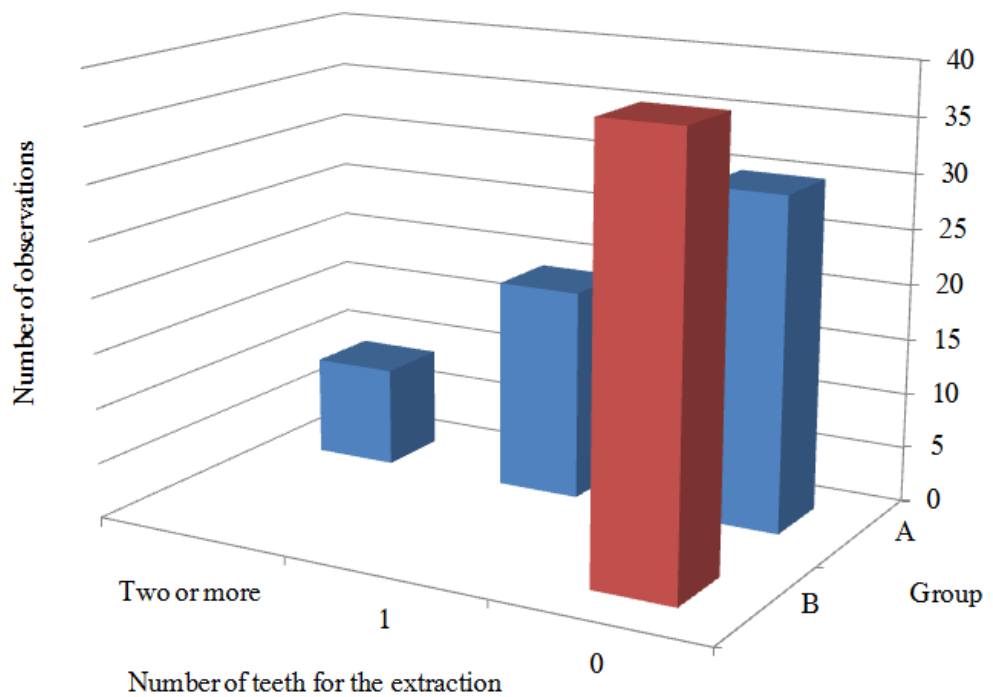

Fig. 3. A graphic representation of the control and study groups in terms of the number of teeth for extraction (red-group B, blue-group A)

Amplification products were detected by an electrophoresis in 2\% agarose gel and stained with ethidium bromide (Table 1). A positive result was characterized by the presence of a band characteristic for the given species: 162 bp corresponded to $P$. intermedia, 255 bp corresponded to A. actinomycetemcomitans and $530 \mathrm{bp}$ to $P$. gingivalis. Amplification product (band) position was determined with a DNA size marker (included in the kit) and a positive control.

\section{Results}

No subjects in the control group (B) showed evidence of gingivitis. In the study group (A), gingivitis was detected in $82.76 \%$ of subjects, with the remaining $17.24 \%$ of subjects shown to be gingivitis-free. The difference between the groups was statistically significant.

No subject in the control group (B) showed visible dental plaque, whereas dental plaque was detected in $100 \%$ of subjects in the study group (A). The difference between these groups was statistically significant.

No tooth extraction was required in $100 \%$ of subjects from the control group (B) and in $51.72 \%$ of subjects from the study group (A). Extraction of 1 tooth was required in $32.76 \%, 2$ teeth in $10.35 \%$ and 3 or more teeth in $5.17 \%$ of group A subjects. The difference between the groups was statistically significant.

Fifty-three subjects from the study group had API of $70-100 \%$, which corresponds to poor oral hygiene and 5 had API of $40-70 \%$, which corresponds to fair oral hygiene. Out of the 39 control group subjects, 30 (77\%) had optimum oral hygiene (API 70-100\%) and 9 (23\%) good oral hygiene (API 25-39\%). The Mann-Whitney U test showed that the median API\% in the study group (poor oral hygiene) was highly significantly greater than that in the control group (good oral hygiene).

The results of PCR-based bacterial DNA detection from the collected dental plaque samples have been presented below.

Figure 4-6, the figures below refer to the study group and show PCR amplification products separated with agarose gel electrophoresis and stained with ethidium bromide; $\mathrm{K}+$ positive control, $\mathrm{K}$ - negative control, $\mathrm{M}$ size markers; bands: 530 bp Porphyromonas gingivalis, 255 bp Aggregatibacter actinomycetemcomitans, 162 bp Prevotella intermedia; 1-60 analyzed samples.

The DNA of Porphyromonas gingivalis was found in none of the subgingival dental plaques. None of the sought-after bacteria were detected in 12 subjects, whereas the DNA of at least one periodontal disease pathogen was found in the remaining 46 subjects. Prevotella intermedia was the most common bacterium, found in 46 subjects, including 32 cases where it cooccurred with Aggregatibacter actinomycetemcomitans. None of the subgingival dental plaque samples showed evidence of Porphyromonas gingivalis DNA. None of the sought-after bacteria were detected in 2 out of 5 subjects with API of $40-70 \%$, while the DNA of both Prevotella intermedia and Aggregatibacter actinomycetemcomitans was found in the remaining 3 subjects. The plaque samples collected as part of the study yielded a number of bacteria. Most children from the study group had 2 bacterial species responsible for periodontal disease: Prevotella intermedia and Aggregatibacter actinomycetemcomitans. This may suggest an increased risk of periodontal diseases in these patients if their oral hygiene habits do not improve. These bacteria may also have a negative impact on the cardiovascular system. 


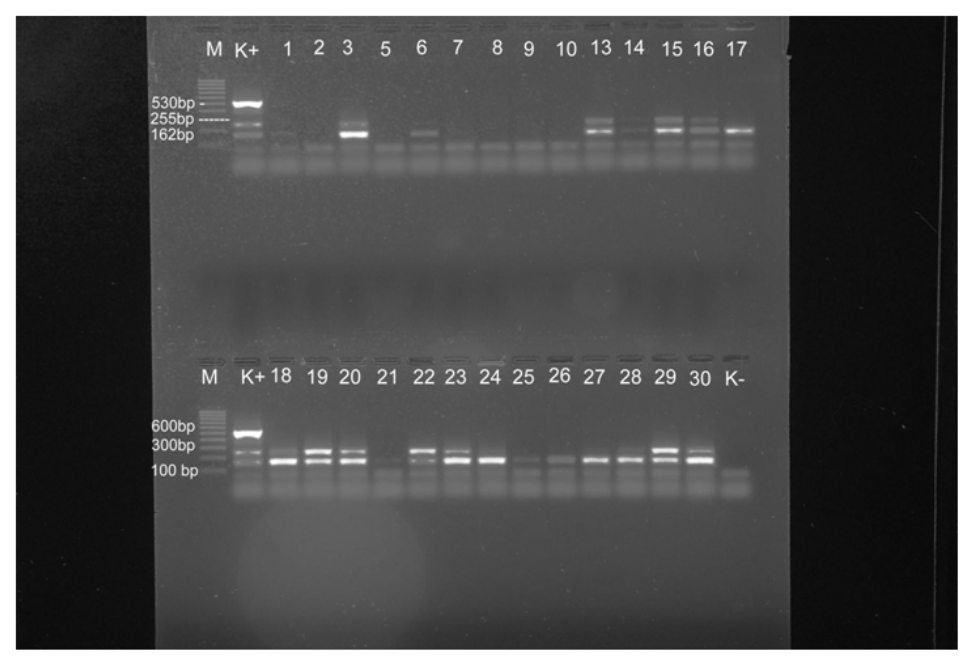

Fig. 4. PCR amplification

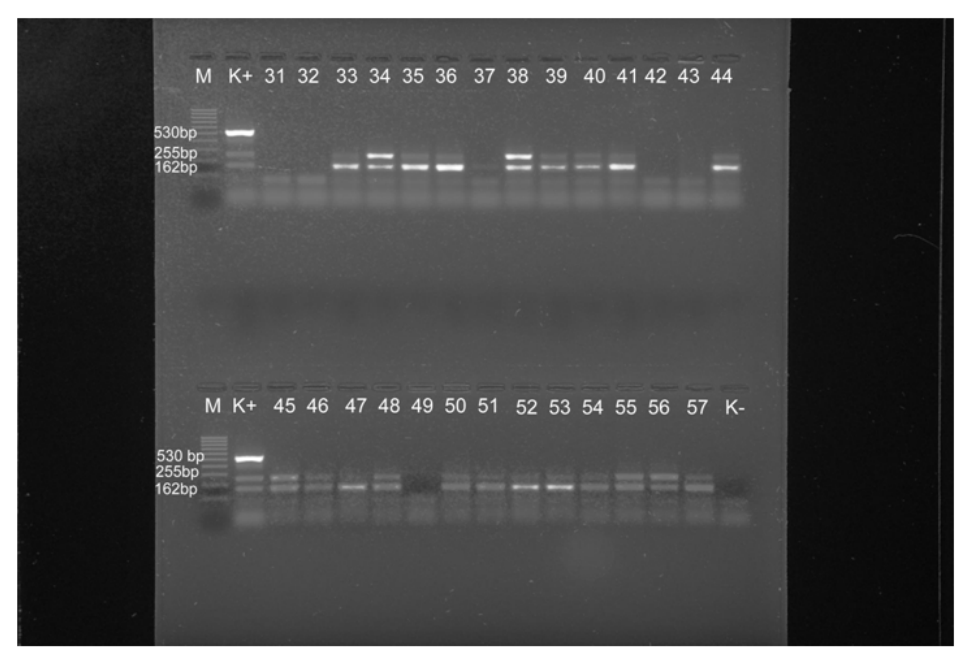

Fig. 5. PCR amplification

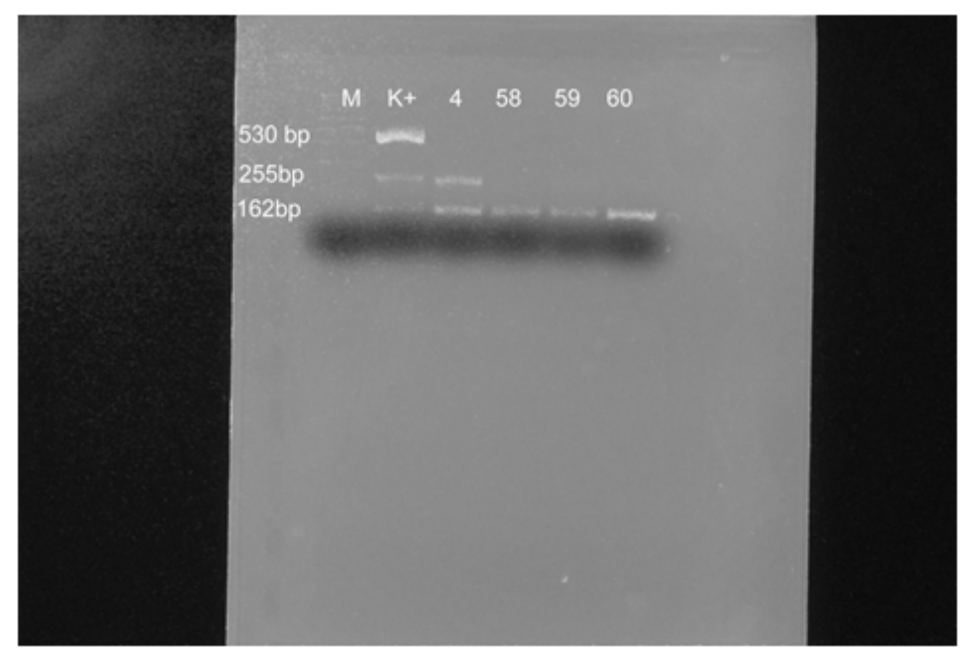

Fig. 6. PCR amplification 


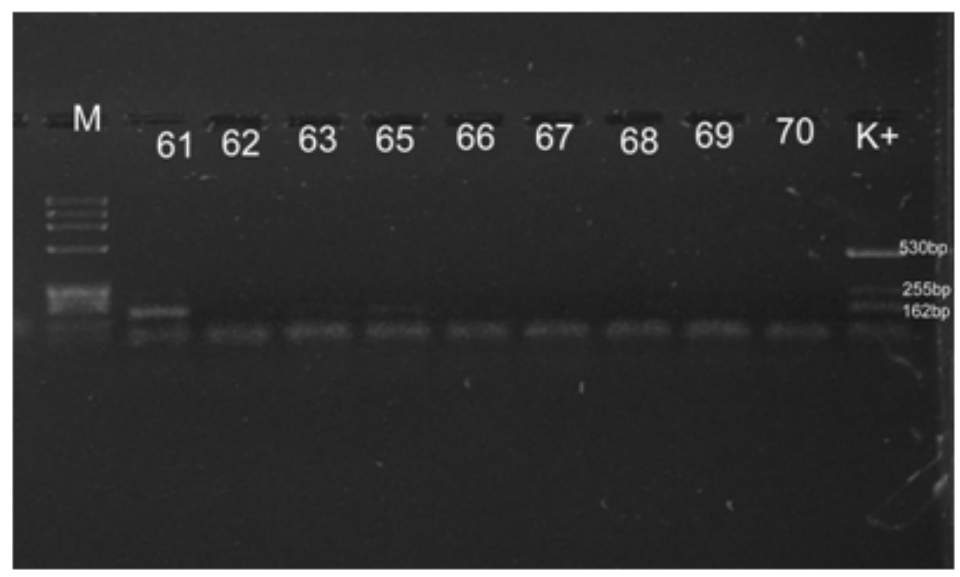

Fig. 7. PCR amplification

Figure 7 the figure below refers to the control group and shows PCR amplification products separated with agarose gel electrophoresis and stained with ethidium bromide; $\mathrm{K}+$ positive control, K-negative control, $\mathrm{M}$ size markers; bands: 530 bp Porphyromonas gingivalis, 255 bp Aggregatibacter actinomycetemcomitans, 162 bp Prevotella intermedia; 61-70 analyzed samples.

The Figure above shows the results obtained in the control group (9 samples collected from subjects without apparent dental plaque). A vast majority of samples (37) yielded no bacterial growth. Two samples yielded Prevotella intermedia. These findings suggest that maintaining good oral hygiene leads to a dramatic reduction in bacterial flora responsible for periodontal disease.

An analysis of risk factors for atherosclerosis demonstrated that the mean homocysteine levels were significantly higher in the study group than in the control group. The rates of high total cholesterol were significantly higher in the study group. The levels of CRP in the children from the study group tended to indicate a higher risk of atherosclerosis.

\section{Discussion}

Nowadays, more and more emphasis is placed both in Europe and worldwide on the relationship between oral and systemic health. According to the prevailing belief, dental medicine teaching programs should include more aspects of general medicine. Dental care has been recognized as an important element of general healthcare. Various studies indicate that mild, chronic inflammation is a significant factor in cardiovascular disease. Such mild, chronic, initially localized inflammation, lasting anywhere from several weeks to several decades, may be caused by periodontal disease. Periodontal disease is believed to be a common inflammatory process and may be an independent risk factor contributing to cardiovascular disease (Rech et al., 2007; Dave and Van Dyke, 2008). One of the key risk factors for periodontal disease is poor oral hygiene, i.e. unsystematic and infrequent toothbrushing (while brushing teeth at least twice a day leads to dental plaque removal) (Franek and Górska, 2009). Nonetheless, the relationship between inadequate oral hygiene in children and the risk of developing atherosclerosis remains unknown. There have been a number of studies on this topic, however, these were typically conducted in adult subjects with advanced periodontal disease (Pussinen et al., 2004; 2007; Renvert et al., 2006). As we did not find any similar studies in children, we compared some of our results to the results of studies conducted in adult study populations.

Based on API assessments, we showed that approximately $91 \%$ of children in our study population had a very poor oral hygiene and $9 \%$ of children-fair oral hygiene. In contrast, the control group showed $77 \%$ of children to have optimum oral hygiene and $23 \%$ good oral hygiene. Mean API\% was highly significantly greater in the study group than in the control group (children with good oral hygiene). The entire study group requires immediate improvement in oral hygiene. Moreover, a number of studies indicate that oral hygiene status in children is highly unsatisfactory (Olczak-Kowalczyk and Bedra, 2003; Giermakowska et al., 1994; Grzesiak and Kaczmarek, 2005; Pires Dos Santos, 2002). The control group was to include children with good oral hygiene and all subjects in this group indeed exhibited sufficient oral hygiene. However, we would like to emphasize that finding subjects for the control group had not been easy because of generally poor oral hygiene in children. This observation demonstrates a very poor condition of oral hygiene in children. Poor oral hygiene in the study group was evidenced by visible dental plaque in all subjects and gingivitis in $82.76 \%$ of children from this group. No patients from the control group had either visible dental plaque or gingivitis. The rates of visible dental plaque and gingivitis were highly statistically significant. Already in 1965, Löe etal. (1965) discovered that 
inadequate oral hygiene may lead to gingivitis (Löe et al., 1965). According to international literature, over $82 \%$ of American adolescents have evident gingivitis gingivitis (Albandar et al., 1998; 2000). The relevant rates in children and adolescents in other parts of the world are comparable or even higher (Albandar et al., 2000). Therefore, considering the likely spread of inflammation, it is crucial to detect the inflammation at the stage of gingivitis, when it is still reversible and before it causes deterioration of the periodontium and the general health (Ziętek, 2000). Otherwise, if left untreated, gingivitis may lead to periodontitis, which involves all tissues of the area and is chronic in nature. Long-standing periodontitis may increase the risk of dental plaque bacteria of gingival and, subsequently, periodontal pockets to negatively affect the general condition of the body including the cardiovascular system. This is emphasized by some authors (Beck and Offenbacher, 2005; Arbes et al., 1999; Geerts et al., 2002; Grzegorczyk-Jaźwińska et al., 2001) such as who evaluated the degree of carotid artery stenosis in a group of 411 adults (Schillinger et al., 2006). The 6-to-9-month follow-up of the group was to help evaluate the correlation of atherosclerotic lesion progression and oral health parameters: Decayed, Missing, Filled (DMF) index, number of teeth, Plaque Index (API) and the Community Periodontal Index of Treatment Needs (CPITN). The authors demonstrated a positive correlation in the case of the first three parameters. A study by (Briggs et al., 2006) included 92 adult males with angiographic evidence of Coronary Artery Disease (CAD). The control group included 79 adult males without $\mathrm{CAD}$, in the same age range as the study group. A comparison of periodontal condition showed a significantly greater number of dental plaque sites, as well as bleeding after probe exploration in the $\mathrm{CAD}$ group, which suggested serious neglect of oral hygiene in this group. Moreover, there was a significant difference in the number of periodontal pockets of $\geq 4 \mathrm{~mm}$ and $\geq 6 \mathrm{~mm}$ in depth. A multivariate logistic regression analysis including socioeconomic and systemic risk factors showed that poor periodontal condition combined with $\geq 6-\mathrm{mm}$ pockets is associated with CAD.

Another oral hygiene-related problem is caries. A total of $82.05 \%$ of children from the control group were cavity-free versus only $12.07 \%$ in the study group. Study group subjects with 1 cavity constituted $17.95 \%$, while subjects with 3 and more cavities constituted $29.31 \%$ of patients each. A staggering $87.93 \%$ of children from the study group were affected by caries, with the mean number of teeth requiring conservative treatment significantly higher than that in the control group. These findings are consistent with those reported by OlczakKowalczyk, who showed that nearly $100 \%$ of children aged 6-8 years and $79 \%$ of children aged 8-12 years were afflicted with caries (Olczak-Kowalczyk and Bedra, 2003). No subject from the control group required tooth extraction due to caries, whereas $51.72 \%$ of subjects from the study group did, with $31.76 \%$ of children from the study group requiring extraction of one tooth and the remaining children-more than one. The difference between these groups was highly statistically significant. This indicates advanced long-standing caries and poor oral hygiene in study group subjects. According to Olczak-Kowalczyk, approximately $50 \%$ of 7 -year-olds required one deciduous or permanent tooth extraction due to caries (Olczak-Kowalczyk, 2001). Elter et al. (2004), who evaluated adults, reported a higher risk of $\mathrm{CAD}$ in patients with a significant number of missing teeth and serious periodontal ligament damage. Holmlund et al. (2006), demonstrated a significant correlation between the diagnosis of myocardial infarction and the mean number of missing teeth. Desvarieux et al. (2003) reported a positive correlation between the number of missing teeth and the number of atherosclerotic lesions in carotid arteries in an ultrasound examination.

The authors mentioned above (Elter, Holmlund, Desvarieux) claimed that significant number of missing teeth may be an indirect sign of advanced, long-lasting periodontal disease (typically resulting from inadequate oral hygiene). The chronic nature of the disease could have had a negative impact on the general condition, as well as the cardiovascular system. This leads us to believe that poor oral hygiene in children, which indicates inadequate oral care habits and multiple teeth qualifying for extraction due to caries may affect the future condition of the oral cavity as well as the entire body.

One important element in the assessment of future cardiovascular risk in children and adolescents is an assessment for CVD due to atherosclerosis in the closest and more remote relatives of the child. CAD in first-degree relatives (parents, siblings) may be a risk factor. Therefore, any positive family history should be documented from a very young age (Williams et al., 2002).

We used the PCR technique for a DNA assessment of bacteria indicative of periodontal disease. Out of the entire oral flora, the bacteria most closely related to the etiology of periodontitis include Porphyromonas gingivalis, Aggregatibacter actinomycetemcomitans and Prevotella intermedia (Buhlin et al., 2003; Marat, 2008; Oliveira et al., 2010; Accarini and De Codoy, 2006; Fardi and Papadimitriou, 2007; Restaino et al., 2007). Over $55 \%$ of patients from the study group (poor oral hygiene) exhibited Aggregatibacter actinomycetemcomitans. These findings were consistent with those by Leys et al. (1994) who used the PCR technique to evaluate dental plaque collected from 52 adults and detected Aa in $60 \%$ of them (Leys et al., 1994). The rate of Aa isolation from diseased sites demonstrates that $\mathrm{Aa}$ is a dominant etiologic factor of early periodontal disease (Armitage, 1999; Affek and Jagusztyn-Krynicka, 2007; Jass et al., 2003). This bacterium was not detected in the control group, which suggests that children from this group maintained good oral hygiene. This bacterium, along with Porphyromonas 
gingivalis and Prevotella intermedia, was also detected in the tunica intima (Marques de Silva et al., 2005) and atherosclerotic plaques (Kozaeov et al., 2005; Oliveira et al., 2010).

Aggregatibacter actinomycetemcomitans may spread beyond the oral cavity and cause or contribute to endocarditis (Paturel et al., 2004).

The second most common bacterium detected in the subgingival dental plaque in the study group was Prevotella intermedia. It was detected in $79 \%$ of subjects (46), including 32 subjects in whom it was co-occurring with Aa. These findings indicate a varied colonization of the oral cavity and an increased risk of periodontal disease, including the risk of atherosclerosis in the near or further future. Górska and Marat evaluated atherosclerotic plaques in the carotid artery with the PCR technique and showed DNA of bacteria, including Aggregatibacter actinomycetemcomitans, Porphyromonas gingivalis and Prevotella intermedia (Górska, 2002; Marat, 2008). Conversely, none of the sought-after bacteria were detected in 37 of 39 subjects in the control group (good oral hygiene). Two samples yielded Prevotella intermedia. This may suggest that maintaining good oral hygiene may contribute to a reduction or elimination of bacteria causing periodontal disease. However, the small sample size in the control group did not allow for drawing any conclusions.

Subgingival dental plaque samples of neither group yielded Porphyromonas gingivalis. This may be due to the fact that this pathogen is most commonly found in advanced stages of periodontal disease in adults, involving periodontal degeneration and alveolar process resorption, which are conditions very rarely found in children (Lau et al., 2004).

A statistical analysis of our study showed a significant difference between the study and control groups in terms of $\mathrm{Pi}$ prevalence. This bacterium was detected more often in the study group (poor oral hygiene). A statistical analysis did not reveal any effect of $\mathrm{Pi}$ on total cholesterol, HDL cholesterol, homocysteine, CRP, fibrinogen or API\% in the study group. These findings may suggest a localized inflammation that has not become generalized yet.

Most subjects from both groups had normal complete blood counts. Additional evaluated parameters included homocysteine, fibrinogen and C-reactive Protein (CRP), which are markers of a general inflammatory response and atherosclerosis. There is a strong correlation between serum CRP levels and the stage of periodontal disease with CRP levels rising in the case of periodontitis (Moutsopoulos and Madianos, 2006; Preshaw et al., 2007; Seymour et al., 2007). The risk of cardiovascular disease exists in both groups, as CRP levels were elevated in only one subject from the study group. Patients with CRP levels below $1.0 \mathrm{mg} / \mathrm{L}$ are believed to have a low risk of developing CVD. Patients with CRP levels ranging from 1.0 to $3.0 \mathrm{mg} / \mathrm{L}$ are at a moderate risk of developing CVD and those with CRP levels over $3.0 \mathrm{mg} / \mathrm{L}$ are considered to be at high risk. A total of 51 subjects from the study group were at moderate risk (CRP 1.0-3.0 mg/L) and 6 subjects were at high risk $(\mathrm{CRP}>3.0 \mathrm{mg} / \mathrm{L})$ of developing CVD. Conversely, 38 subjects from the control group showed moderate risk of developing CVD and 1 subject-high risk. This demonstrates a slightly higher risk in the study group. A study by Dye et al. (2005) demonstrated that one factor affecting elevated CRP levels is a high level of anti-Pg antibodies. These results show that the presence of this bacterium means an existing severe inflammation in the oral cavity that, in turn, causes elevated CRP levels. We did not detect $P g$ in any subject, which indicates a small, still localized inflammation that corresponds to low CRP levels. Moreover, a statistical analysis did not show significant differences between the two groups in terms of CRP. Homocysteine levels in both groups were within normal limits, as well as fibrinogen levels in most children. However, a statistical analysis showed that the mean homocysteine levels are significantly higher in the study group than those in the control group. Elevated blood homocysteine levels are an independent risk factor for the development of cardiovascular disease. Fibrinogen test results may indicate a lack of current atherosclerotic lesions in the vascular endothelium. We would like to emphasize, nonetheless, that fibrinogen levels were not statistically significant.

A lack of changes in the above markers may indicate a mild, still localized inflammation. If such localized inflammation (as well as poor oral hygiene) persists in children for many years, it may become generalized. In adulthood, those affected are at a higher risk of developing acute coronary syndrome and show elevated plasma CRP and fibrinogen levels (Zaremba et al., 2005).

We also assessed total cholesterol and HDL cholesterol levels, with the latter found within normal limits in most subjects. The differences between groups were not statistically significant. However, total cholesterol levels were elevated in $14(24.14 \%)$ children from the study group and in $2(5.13 \%)$ children from the control group. A statistical analysis showed that by informing her that oral care is important for her own health in general and the child's health in particular. Young children, their guardians (parents, nursery and pre-school personnel), as well as pediatricians need health-promoting more stable, less labile total cholesterol levels can be observed in the control group. The Student $t$ or Mann-Whitney U tests did not show any statistically significant differences between the groups, however, the test for differences between two structure indicators showed that the groups differed significantly in terms of cholesterol levels, with the study group (poor oral hygiene) showing significantly higher total 
cholesterol levels. We found no reports in the available literature on the level of total cholesterol in children with respect to oral hygiene. This may suggest a need for thorough future studies on total cholesterol levels in children with poor and good oral hygiene. Thus, in order to determine whether or not elevated total cholesterol levels may be a risk factor for atherosclerosis in children with poor dental hygiene, further studies are needed because a single study does not allow for adequate conclusions to be drawn.

Both groups of subjects also underwent complete blood count assessment. No relevant abnormalities were detected.

In summary, there are no current studies on whether or not adequate oral hygiene in children affects atherosclerosis formation. Studies on other inflammation markers are currently being planned. This study proved that poor oral hygiene is related to the presence of indicator bacteria of the periodontium in children. This is a disturbing phenomenon that requires more attention and thorough investigation in the nearest future.

This phenomenon is important not only for maintaining oral health from a very young age, but also for maintaining general health. It is important to help develop positive routines of constant oral care in adult life. As the first teachers, parents should ensure systematic toothbrushing in their children, introduction of suitable dietary habits and observing adequate frequency of routine dental visits. It is necessary to make adults (parents) realize that there is a relationship between periodontal disease with the resulting inflammation and other systemic conditions. The greatest medical authority for the parents of a child is a pediatrician who should offer advice on the child's proper oral hygiene and suitable diet. It is a pediatrician who should make parents aware of the necessity to have their child see a dentist who will recommend adequate hygiene of the gums and, later, erupting teeth. The gynecologist who takes care of the mother during her pregnancy and postpartum period also plays an important role educational initiatives. It is very important that neither healthcare professionals nor patients perceive gingivitis only as a pre-cursor of periodontitis, but also realize that gingivitis and periodontitis may negatively affect general health. Such actions may have a positive impact on healthoriented prophylactic habits in the society as well as contribute to reducing cardiac mortality.

\section{Conclusion}

- The level of oral hygiene in children is highly unsatisfactory. Thus, good oral care habits need to be cultivated in children from a very young age

- Children with poor and fair oral hygiene (according to API) exhibited periodontal disease-causing bacteria that may induce chronic inflammation, which is a risk factor for atherosclerosis

- Children with good and adequate oral hygiene (according to API) showed a reduction in periodontal disease-causing bacteria in subgingival dental plaque, with no bacteria detected in most cases

- Based on CPR levels, both groups are at risk of cardiovascular disease. That risk tended to increase in the study group (poor oral hygiene)

- Parents should take more measures to help their children maintain oral hygiene by monitoring toothbrushing duration and technique, as well as reviewing thoroughness of brushing in their children

- Dentists should pay more attention to teaching oral hygiene to adults and especially to children. Parents need to be made aware that there is a correlation between good oral hygiene and general health

- Children with positive genetic history, the presence of periodontal disease-causing bacteria and inflammatory reaction constitute a higher risk group for the development of atherosclerosis in the future

\section{Author's Contributions}

All authors equally contributed in this work.

\section{Ethics}

This article is original and contains unpublished material. The corresponding author confirms that all of the other authors have read and approved the manuscript and no ethical issues involved.

\section{References}

Accarini, R. and M.F. De Codoy, 2006. Periodontal disease as a potential risk factor for acute coronary syndromes. Arq. Bras. Cardiol., 87: 539-543. DOI: 10.1590/S0066-782X2007000200019

Affek, K. and E.K. Jagusztyn-Krynicka, 2007. Molekularna charakterystyka czynników wirulencji Actinobacillus actinomycetemcomitans. Post Mikrobiol., 46: 113-123.

Albandar, J.M., A. Kingman, L.J. Brown and H. Löe, 1998. Gingival inflammation and subgingival calculus as determinants of disease progression in early-onset periodontitis. J. Clin Periodontol., 25: 231-237. DOI: 10.1111/j.1600-051X.1998.tb02433.x

Albandar, J.M. and T.E. Rams, 2002. Global epidemiology of periodontal diseases: An overview. Periodontolgy, 29: 7-10. DOI: 10.1034/j.1600-0757.2002.290101.x

Arbes, S.J., G.D. Slade and J.D. Beck, 1999. Association between extent of periodontal attachment loss and self-report history of heart attack: An analysis of NHANES III data. J. Dent. Res., 78: 1777-82. DOI: $10.1177 / 00220345990780120301$ 
Armitage, G.C., 1999. Development of a classification system for periodontal diseases and conditions. Ann Periodontol., 4: 1-6. DOI: 10.1902/annals.1999.4.1.1

Beck, J.D. and S. Offenbacher, 2005. Systemic effects of periodontitis: epidemiology of periodontal disease and cardiovascular disease. J. Periodontol., 76: 2089-2100. DOI: 10.1902/jop.2005.76.11-S.2089

Bouchard, P., P. Boutouyrie, F.D’Aiuto, J. Deanfield and Efthymios Deliargyris et al., 2010. European workshop in periodontal health and cardiovascular disease consensus document. Eur. Heart J., 12: B13-B22. DOI: 10.1093/eurheartj/suq001

Briggs, J.E., P.P. McKeown, V.L. Crawford, J.V. Woodside and R.W. Stout et al., 2006. Angiographically confirmed coronary heart disease and periodontal disease in middle-aged males. J. Periodontol., 77: 95-102. DOI: 10.1902/jop.2006.77.1.95

Buhlin, K., A. Gustafsson, A.G. Pockley, J. Frostegård and B. Klinge, 2003. Risk factors for cardiovascular disease in patients with periodontitis. Eur Heart J., 24: 2099-2107. DOI: 10.1016/j.ehj.2003.09.016

Dave, S. and T.E. Van Dyke, 2008. The link between periodontal disease and cardiovascular disease is probably inflammation. Special Revi. Periodontal Medicine. Oral Dis., 14: 95-101. PMID: 18302669

Desvarieux, M., R.T. Demmer, T. Rundek, B. BodenAlbala and D.R. Jacobs et al., 2003. Relationship between periodontal disease, tooth loss and carotid artery plaque: The oral infections and vascular disease epidemiologic study (INVEST). Stroke, 34: 2120-25. DOI: 10.1161/01.CIR.0000154582.37101.15

Dye, B.A., K. Choudhary, S. Shea and P. N. Papapanou, 2005. Serum antibodies to periodontal pathogens and markers of systemic inflammation. J. Clin Periodontol., 32: 1189-99. PMID: 16268994

Elter, J.R., C.M. Champagne, S. Offenbacher and J.D. Beck, 2004. Relationship of periodontal disease and tooth loss to prevalence of coronary heart disease. J. Periodontol., 75: 782-90. PMID: 15295942

Fardi, A. and D. Papadimitriou, 2007. Periodontal and atherosclerosis-induced diseases. Systematic reviews. Intern. Angiol., 26: 197-205. PMID: 17622199

Franek, E. and R. Górska, 2009. Choroby przyzębia a układ sercowo-naczyniowy-kliniczna interpretacja badania stomatologicznego. Choroby Serca I Naczyń., 6: 142-146.

Geerts, S.O., M. Nys, M.P. De, J. Charpentier and A. Albert et al, 2002. Systemic release of endotoxins induced by gentle mastication: Association with periodontitis severity. J. Periodontol., 73: 73-78. PMID: 11846202

Giermakowska, A., E. Gielniewska, Z. Chraniuk, P. Kawka and P. Okoński et al., 1994. Wpływ higieny i diety na występowanie próchnicy u dzieci po 3 roku życia. Magazyn Stomat., 4: 9: 19-23.
Górska, R., 2002. Choroby Przyzębia. 1st Edn., Akademia Medyczna, Warszawa, ISBN-10: 8388559451, pp: 176.

Górska, R., 2009. Sprawozdanie z niezależnego panelu ekspertów na temat związku chorób przyzębia $\mathrm{z}$ chorobami ogólnoustrojowymi. Kardiol Pol., 67: 708-710.

Grzegorczyk-Jaźwińska, A., R. Górska, R. Stawicka, M. Borakowska and M. Zaremba et al., 2001. Poziom cytokin prozapalnych a stan przyzębia u pacjentów $\mathrm{z}$ chorobami układu sercowo-naczyniowego. Stom Współczesna., 8: 17-20.

Grzesiak, I. and U. Kaczmarek, 2005. Prognozowanie stanu higieny jamy ustnej u dzieci. Dent. Med. Probl., 42: 2: 255-260.

Haake, S.K., M.G. Newman, R.J. Niesengard and M. Sanz, 1996. Periodontal microbiology. Clinical Periodont.

Holmlund, A., G. Holm and L. Lind, 2006. Severity of periodontal disease and number of remaining teeth are related to the prevalence of myocardial infarction and hypertension in a study based on 4254 subjects. J. Periodontol., 77: 1173-78. PMID: 16805679

Jass, J., S. Surman and J. Walker, 2003. Medical Biofilms, Detection, Prevention and Control. 1st Edn., John Wiley and Sons, Chichester, ISBN-10: 0471988677 , pp: 291.

Kozaeov, E.V., B.R. Dorn, C.E. Shelburne, W.A. Dunn and A. Progulske-Fox, 2005. Human atherosclerotic plaque contains viable invasive Actinobacillus actinomycetemcomitans and Porphyromonas gingivalis. Arterioscler Thromb Vasc Biol., 25: e17-e18. PMID: 15662025

Lange, D.E., 1978 Mundhygienekontrollen bei instruierten und motivierten patienten in prophylaxe. Quintessenz Verlag Berlin.

Lau, L., M. Sanz, D. Herrera, J.M. Morillo and C. Martin et al., 2004. Quantitative real-time polymerase chain reaction versus culture: A comparison between two methods for the detection and quantification of Actinobacillus actinomycetemcomitans, Porphyromonas gingivalis and Tannerella forsythensis in subgingival plaque samples. J. Clin Periodontol., 31: 1061-1069. DOI: 10.1111/j.1600-051X.2004.00616.X

Leys, E.J., A.L. Griffen, S.J. Strong and P.A. Fuerst, 1994. Detection and strain identification of Actinobacillus actinomycetemcomitans by nested PCR. J. Clin. Microbiol., 32: 5: 1288-94. PMID: 8051258

Löe, H.E., E. Theilade and S. B. Jensen, 1965. Experimental gingivitis in man. J. Periodontol., 36: 177-177. PMID: 14296927

Marat, A., 2008. Leczenie periodontologiczne pacjentów przewlekle przyjmujących terapię przeciwzakrzepową. Nowa Stomatologia, 1: 27-30. 
Marques de Silva, R., D.A. Caugant and P.S. Lingaas et al., 2005. Detection of Actinobacillus actinomycetemcomitans but not bacteria of the red complex in aortic aneurysms by multiplex polymerase chain reaction. J. Periodontol., 76: 590-594.

Moutsopoulos, N.M. and P.N. Madianos, 2006. Lowgrade inflammation in chronic infectious diseases. Ann NY Acad Sci., 1088: 251-264. PMID: 17192571

Norskov-Lauritsen, N. and M. Kilian, 2006. Reclassification of Actinobacillus actinomycetemcomitans, Haemophilus aphrophilus, Haemophilus segnis as Aggregatibacter actinomycetemcomitans gen. nov., comb. nov., Aggregatibacter aphrophilus comb. nov. and Aggregatibacter segnis comb. nov. and emended description of Aggregatibacter aphrophilus to include $\mathrm{V}$ factor-dependent and $\mathrm{V}$ factor-independent isolates. IJSEM., 56: 2135-2146. DOI: 10.1099/ijs.0.64207-0

Olczak-Kowalczyk, D., 2001. Ocena stanu higieny jamy ustnej i uzębienia u dzieci warszawskich w wieku od 3 do 7 roku życia. Nowa Stomatologia., 4: 13-21.

Olczak-Kowalczyk, D. and B. Bedra, 2003. Stan zdrowia jamy ustnej i stomatologiczne potrzeby lecznicze w badanej populacji dzieci z ryzykiem infekcyjnego zapalenia wsierdzia. Nowa Stomatologia., 3: 11-18.

Oliveira, F.J., R.W. Vieira and O.R. Coelho, O. Petrucci and P.P.M. de Oliveira et al., 2010. Systemic inflammation caused by chronic periodontitis in acute ischemic heart attack patients. Rev. Bras Cir Cardiovasc., 25: 51-58. DOI: $10.1590 / \mathrm{S} 0102-76382010000100013$

Paturel, L., J.P. Casalta, G. Habib, M. Nezri and D. Raoult, 2004. Actinobacillus actinomycetemcomitans endocarditis. CMI., 10: 98-118. PMID: 14759235

Pires Dos Santos, A.P., 2002. Caries prevalence and risk factors among children aged 0-36 months. Pesqui Odontol. Bras., 16: 203-208.

Preshaw, P.M., N. Foster and J.J. Taylor, 2007. Crosssusceptibility between periodontal disease and type 2 diabetes mellitus: An immunobiological perspective. Periodontol, 45: 138-156. PMID: 17850454

Pussinen, P.J., G. Alfthan, P. Jousilahti, S. Paju and J. Tuomilehto, 2007. Systemic exposure to Porphyromonas gingivalis predicts incident stroke. Atherosclerosis, 193: 222-228. PMID: 16872615

Pussinen, P.J., G. Alfthan, J. Tuomilehto, S. Asikainen and P. Jousilahti, 2004. High serum antibody levels to Porphyromonas gingivalis predict myocardial infarction. Eur. J. Cardiovasc Prev. Rehabil., 11: 408-411. DOI: 10.1097/00149831-200410000-00008

Rech, R.L., N. Nurkin and J.D. Cruz, F. Sostizzo and C. Baião et al., 2007. Association between periodontal disease and acute coronary syndrome. Arq. Bras. Cardiol., 88: 162-166. PMID: 17384836
Renvert, S., T. Pettersson, O. Ohlsson and G. R. Persson, 2006. Bacterial profile and burden of periodontal infection in subjects with a diagnosis of acute coronary syndrome. J. Periodontal., 77: 1110-1119. PMID: 16805672

Restaino, C.G., A. Chaparro, M.A. Valenzuela, A.M. Kettlun and R. Vernal et al., 2007. Stimulatory response of neutrophils from periodontitis patients with periodontal pathogens. Neutrophil response in periodontitis patients. Oral Dis., 13: 474-481. DOI: $10.1111 / \mathrm{j} .1601-0825.2006 .01323 . x$

Ridker, P.M., 1999. Evaluating novel cardiovascular risk factors: Can we better predict heart attacks? Ann. Intern. Med., 130: 933-937. PMID: 10375342

Schillinger, T., W. Kluger, M. Exner, W. Mlekusch and S. Sabeti et al., 2006. Dental and periodontal status and risk for progression of carotid atherosclerosis: The inflammation and carotid artery risk for atherosclerosis study dental substudy. Stroke, 37: 2271-6. DOI: 10.1161/01.STR.0000236495.82545.2e

Seymour, G.J., P.J. Ford, M.P. Cullinan, S. Leishman and K. Yamazaki, 2007. Relationship between periodontal infections and systemic disease. Clin Microbiol Infect., 13: 3-10. DOI: 10.1111/j.1469-0691.2007.01798.x

Southerland, J.H., G.W. Taylor, K. Moss, J.D. Beck and S. Offenbacher, 2006. Commonality in chronic inflammatory disease: Periodontitis, diabetes and coronary artery disease. Periodontology, 40: 130-143. PMID: 16398690

Szyguła-Jurkiewicz, B., R. Wojnicz and L. Poloński, 2004. Rola zapalenia W patogenezie ostrych zespołów wieńcowych. Od niestabilnej blaszki miażdżycowej do obwodowych markerów zapalenia. Pol. Arch. Med. Wewn., 111: 269-274.

Urban, M., 2007. Miażdżyca u Dzieci I Młodzieży. 1st Edn., Cornetis, Wrocław, ISBN-10: 839195403X, pp: 448.

Williams, C.L., L.L. Hayman, S.R. Daniels, T.N. Robinson and J. Steinberger et al., 2002. Cardiovascular health in childhood: A statement for health professionals from the Committee on Atherosclerosis, Hypertension and Obesity in the Young (AHOY) of the council on cardiovascular disease in the young, american heart association. Circulation, 106: 143-160. PMID: 12093785

Zaremba, M., R. Górska and P. Suwalski, 2005. Ocena występowania bakterii związanych $\mathrm{Z}$ chorobą przyzębia w blaszce miażdżycowej naczyń wieńcowych. Czas Stomat., LVIII, 5: 293-301.

Ziętek, M., 2000. Immunopatologia Błony Śluzowej Jamy Ustnej W: Immunologia kliniczna. Kowalski M.L., (Eds.), Mediton Oficyna Wydawnicza, Łódź, pp: 593-606. 